UDC 536.37

\title{
Particularities of Exergy Analysis in Air Conditioning Systems
}

\author{
V. I. Prokhorov ${ }^{1)}$, S. V. Troyanchuk ${ }^{1)}$, M. A. Razakov ${ }^{1,2)}$ \\ ${ }^{1)}$ Moscow State University of Civil Engineering (Moscow, Russian Federation), \\ ${ }^{2)}$ Moscow Power Engineering Institute (Moscow, Russian Federation) \\ (C) Белорусский национальный технический университет, 2022 \\ Belarusian National Technical University, 2022
}

\begin{abstract}
The paper examines two methods of choosing the initial reference point for exergy of the moist air flow. The first method is characterized by a zero exergy value at the current temperature and humidity of the outdoor air, which are variable both in daily and annual periods. Another is characterized by constant values of parameters of moist indoor air (its temperature and humidity in the room). A comparative study has shown the advantages of the second method: greater stability of values in air processing processes and their convenient presentation on exergy chart. However, it should be noted that this method provides a non-standard technical representation in which the entire energy flow is reduced to zero. The climatic information (temperature and humidity of the outside air) for numerical-analytical experiment has been used from official open sources. The city where the air conditioning system was supposedly installed is Stavropol. The research has been carried out in the summer and cold periods of the year. It is assumed that there are not installed any large heat sources in the room and the main heat sources appeared depending on the period of the year. Additionally, the air conditioning system was equipped with a recirculation line from the serviced room with a mechanical ventilator. The recirculated air entered the mixing chamber in the air conditioning unit which is reducing the consumption of heat energy in the cold season. There are the processes of air conditioning on the Ramzin's $h$ - $d$-diagram for warm and cold operational modes of air conditioning unit, the air conditioning system under consideration.
\end{abstract}

Keywords: exergy, exergy chart, $h$-d-diagram, air conditioning, energy saving, moist air, energy

For citation: Prokhorov V. I., Troyanchuk S. V., Razakov M. A. (2022) Particularities of Exergy Analysis in Air Conditioning Systems. Science and Technique. 21 (1), 42-49. https://doi.org/10.21122/2227-1031-2022-21-1-42-49

\section{Особенности эксергетического анализа в системах кондиционирования воздуха}

\author{
Докт. техн. наук, проф. В. И. Прохоров ${ }^{1)}$, инж. С. В. Троянчук'), асп. М. А. Разаков ${ }^{1,2)}$ \\ ${ }^{1)}$ Московский государственный строительный университет (Москва, Российская Федерация), \\ ${ }^{2)}$ Московский энергетический институт (Москва, Российская Федерация)
}

Реферат. Исследуются два метода выбора начальной точки отсчета эксергии потока влажного воздуха. Первый характеризуется нулевым значением эксергии при текущей температуре и влажности наружного воздуха, которые изменяются как в суточные, так и в годовые периоды, другой - постоянными значениями параметров влажного внутреннего воздуха (его температуры и влажности в помещении). Сравнительное исследование показало преимущества второго метода: большую стабильность значений в процессах обработки воздуха и удобное их представление на эксергетической диаграмме. Однако следует отметить, что данный метод дает нестандартное техническое представление, в котором весь поток энергии сводится к нулю. Для численно-аналитического эксперимента использовали климатические данные (температуру и влажность наружного воздуха) из официальных открытых источников. Город, где предположительно была установлена система кондиционирования воздуха, - Ставрополь. Проведение исследований осуществлялось в летний и холодный периоды года. Принимали, что в помещении нет крупных источников теплоты, а основные из них появлялись в зависимости от периода года. Дополнительно система кондиционирования

\section{Адрес для переписки}

Разаков Мухаммет Азатович

Московский энергетический институт

ул. Красноказарменная, 14,

111250, г. Москва, Российская Федерация

Тел.: +7 495 362-70-01

muhammet@nln.ru

\author{
Address for correspondence \\ Razakov Muchammet A. \\ Moscow Power Engineering Institute \\ 14, Krasnokazarmennaya str., \\ 111250, Moscow, Russian Federation \\ Tel.: +7 495 362-70-01 \\ muhammet@nln.ru
}


воздуха оборудовалась рециркуляционной линией из обслуживаемого помещения с механическим побуждением. Рециркуляционный воздух попадал в камеру смешения в приточной установке, тем самым обеспечивая сокращение расхода тепловой энергии в холодный период года. Приведены процессы обработки воздуха на $h-d$-диаграмме Рамзина для теплого и холодного режимов работы приточной установки, рассматриваемой системы кондиционирования воздуха.

Ключевые слова: эксергия, диаграмма эксергии, $h-d$-диаграмма, кондиционирование воздуха, энергосбережение, влажный воздух, энергия

Для цитирования: Прохоров, В. И. Особенности эксергетического анализа в системах кондиционирования воздуха / В. И. Прохоров, С. В. Троянчук, М. А. Разаков // Наука и техника. 2022. Т. 21, № 1. С. 42-49. https://doi.org/10. 21122/2227-1031-2022-21-1-42-49

\section{Introduction}

As a rule, the analysis of energy parameters of air conditioning systems is carried out using the balance method, taking into account only the first law of thermodynamics. The drawback of this method is that it does not differentiate types of energy and their energy value in relation to the environment. The very concept of the environment is hidden in the analysis, and the strengths and weaknesses of individual processes and sectors of the energy-consuming system are not disclosed. Therefore, the method of thermodynamic analysis using the concept of exergy (a workable part of energy) has, in our opinion, insufficiently employed reserves.

The classical development of the exergy method of thermodynamic analysis was commenced in the end of the XIX century (A. Stodola, L. Guye) and continued during the entire twentieth century (Z. Rant, Ya. Shargut, R. Petela, V. M. Brodyansky, V. S. Martynovsky, S. S. Dolinsky and others).

The exergy method of thermodynamic analysis is based both on the first and the second laws of thermodynamics and allows to take into account the quality of energy in terms of obtaining a useful effect under specific environment conditions $(t$ and $d)$ [1-4]. Based on the evaluation of purely physical processes, the exergy method allows to find the most important areas of application of energy-saving engineering [5-8] and to define new technical requirements for air conditioning systems ensuring their "innovative" development [9]. At the moment, the method under consideration has found application in many branches of industry [10-12].

Although the state of the system with the minimum potential difference relative to the environment has traditionally been selected as the reference point for exergy, this choice is complicated in case of air conditioning systems because there is no stability of environment conditions [13-15] and the value of exergy increment of air flow is signvariable.

\section{Methods of exergy efficiency assessment}

Efficiency of major units of air conditioning installation. While attempting to assess the efficiency of the air conditioner unit, it is necessary to correlate the exergy difference of the moist air flow (useful effect in this unit or device) with the exergy expenditures, which include exergy differences of heat transfer medium, mass transfer, electrical capacity of pump drives, ventilators or other means for creating differential air pressure in the conditioner units or in the ductworks.

Formation of the exergy balance in the mixing chamber can result in the following expression:

$$
E_{R}+G_{r}+E_{O} G_{I}=\left(G_{I}+G_{r}\right) E_{M},
$$

where $E_{R}$ - exergy of the moist air flow in the room; $G_{r}$ - mass flow of the recirculated air; $E_{O}-$ exergy of the moist outdoor air flow; $G_{I}$ - mass flow of the inlet air; $E_{M}$ - exergy of the air flow mixture.

After simple algebraic transformations and with regard to the zero reference level of exergy, introduced earlier

$$
G_{r} E_{M}=\left(E_{O}-E_{M}\right) G_{I} .
$$

The right-hand member expresses the useful effect of the process of air flows mixing, and the left-hand member expresses the expended air exergy. Taking into account the expenditures of the electrical energy, it is possible to formulate the exergetic efficiency factor for the mixing chamber in the winter season in the form of the following expression: 


$$
\bar{e}_{\text {mixing chamber }}=\frac{G_{I}\left(E_{O}-E_{M}\right)}{G_{r} E_{M}+N_{r} G_{r}+N_{5}\left(G_{r}+G_{I}\right)},
$$

where $N_{r}$ - energy expended by the recirculating ventilator; $N_{5}$ - amount of energy of the suction ventilator expended on the overcoming of aerodynamic resistance of the air mixing chamber.

The notation should be introduced $G_{r} / G_{I}=a$. Then the exergy efficiency factor for the mixing chamber may be written as follows:

$$
\bar{e}_{\text {mixing chamber }}=\frac{E_{O}-E_{M}}{a E_{M}+a N_{r}+N_{5}(1+a)},
$$

where $a$ - ratio between $G_{r}$ and $G_{I}$.

In the summer season (due to the heating of air in the recirculating duct) the expression (4) will be written as follows:

$$
\bar{e}_{\text {mixing chamber }}=\frac{E_{O}-E_{M}}{a\left(E_{M}-E_{R}\right)^{\prime}+a N_{r}+N_{5}(1+a)} \text {. }
$$

The air heater efficiency is the ratio of the air exergy change to the change of heat transfer medium exergy and the expended electrical energy

$$
\bar{e}_{\text {calorifier }}=\frac{\Delta E_{\text {air }}}{\Delta E_{\text {heat transfer med }}+N_{2,4}},
$$

where $\Delta E_{\text {air }}$ - difference between exergy of air flow mixture and air before air washer; $\Delta E_{\text {heat transfer med }}-$ the change of heat transfer medium exergy; $N_{2,4}-$ expended electrical energy ensuring the operation of this unit.

The air washer efficiency is the ratio of the air exergy difference in this unit to the change of water exergy and the expended electrical energy

$$
\bar{e}_{\text {air washer }}=\frac{\Delta E_{\text {air }(1)}}{\Delta E_{\text {water }}+N_{3}},
$$

where $\Delta E_{\text {air(1) }}$ - difference between exergy of air after air washer and air before air washer; $\Delta E_{\text {water }}-$ the change of water exergy; $N_{3}$ - aggregate expenditures of electrical energy of pumps, ventilators, and other devices ensuring the operation of this unit.

Exergy efficiency of the air conditioning system. The efficiency of the air conditioning system in a simplified form can be assessed by the correlation of the change in the inlet air exergy (conditioning process, which is useful, assimilating heat- and-moisture excesses in the room) with the change of exergy immediately after the ingress of air in the air conditioning installation until the exit of air from it.

The simplified analytical expression of the efficiency is written as follows:

$$
\bar{e}=\frac{E_{I}-E_{R}}{E_{O}-E_{I}},
$$

where $E_{I}$ - exergy of the moist air flow at the entrance to the room.

Taking into consideration the zero level of exergy, taken in this paper as $E_{R}=0$ :

$$
\begin{gathered}
\bar{e}=\frac{E_{I}}{E_{O}-E_{I}} ; \\
\bar{e}=\frac{\left|\Delta E_{1}\right|}{\left|\Delta E_{2}\right|+\left|\Delta E_{3}\right|+\left|\Delta E_{4}\right|+\left|\Delta E_{5}\right|} .
\end{gathered}
$$

As the reference level of exergy, taken by us, is constant, there is no need to recalculate all the values of the flow exergy in the context of the change in the outdoor air parameters, only the $E_{\text {in }}$ or $\Delta E_{5}$ should be recounted.

With regard to expressions (4), (4'), (5) and (6) the exergy efficiency of the air conditioning system can be represented as a chart (Fig. 1), where values of expended exergy are singled out on the $X$-axis, and values of useful exergy are singled out on the $Y$-axis.

In the summer season the preheating air heater is turned off, however, it creates the aerodynamic resistance to the movement of the air flow. Thus, $N_{4}^{\prime}$ expresses the fraction of the electrical energy of the ventilator, required for the overcoming of the aerodynamic resistance of the turned off air heater. The aggregate expenditures of the electrical energy by the ventilator can be written as follows:

$$
N_{1}+N_{2}+N_{3}+N_{4}+N_{5}=N_{R},
$$

where $N_{1}$ - expenditure of electrical energy of the ventilator on the overcoming of the aerodynamic resistance of the ductwork (authors decided not to include this expenditure due to its extremely specific calculation); $N_{2}, N_{3}, N_{4}, N_{5}$ - expenditures of the electrical energy of the ventilator on the overcoming of the aerodynamic resistance of the reheat air heater, air washer, preheating air heater and mixing chamber. 

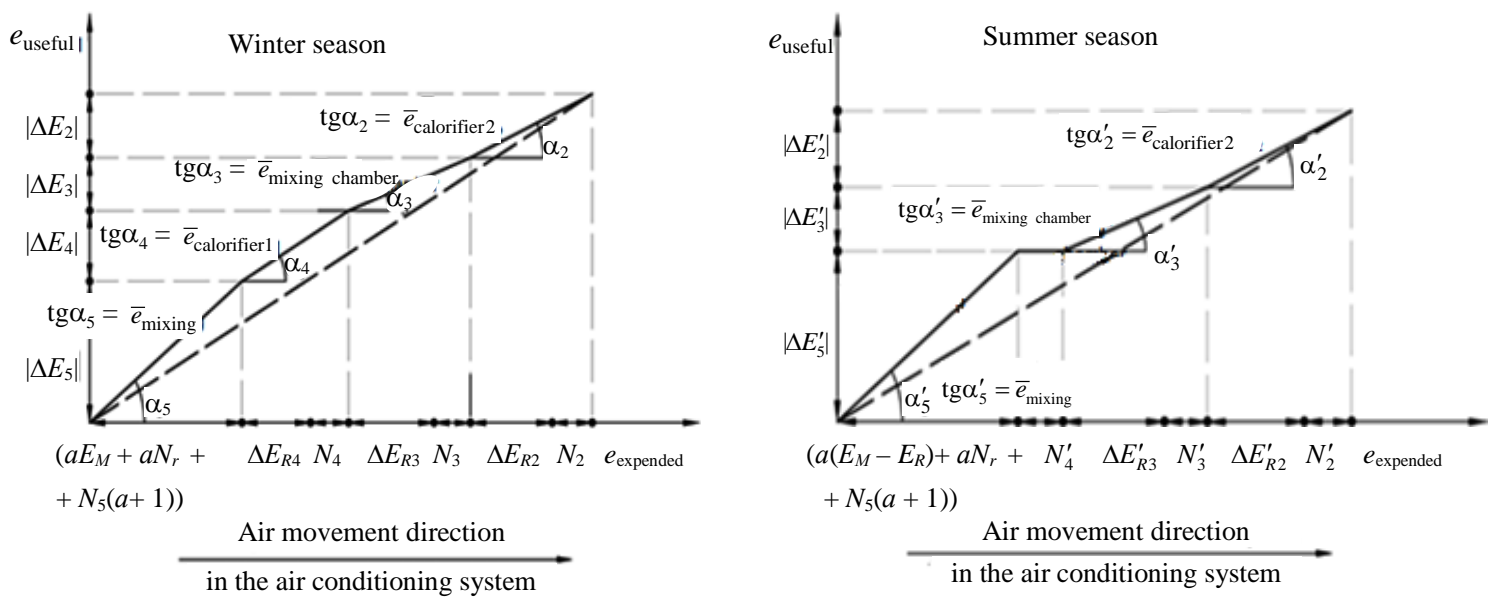

Fig. 1. Graphical determination of the air conditioning system efficiency

The results from expressions (4), (4'), (5) and (6), as well as Fig. 1 that in order to increase the exergy efficiency of the air conditioning system it is necessary to reduce the amount of the expended electrical energy. It can be achieved by the reduction of aerodynamic resistances of units of the air conditioning system, hydraulic resistances in the air washer, optimization of the ventilator performance. This analysis is most appropriate to be conducted precisely when selecting the zero reference point of exergy in the attended room, since this makes it convenient to graphically and analytically depict the exergy efficiency of the air conditioning system.

\section{Results and discussion. \\ Rationale for introduction of the new reference point for exergy}

Depending on the area of construction, the average daily temperature difference can exceed $10{ }^{\circ} \mathrm{C}$, and the average annual temperature can exceed $50{ }^{\circ} \mathrm{C}$. Relative humidity varies from 20 to $100 \%$. Such an amplitude of temperature and humidity fluctuations leads to inconvenience in calculating the exergy efficiency of systems and equipment for creating a given airthermal microclimate. It is also difficult to compare effectiveness of the different versions of systems. It has been considered the change in state of the Stavropol climate region. There are the climatic data from official open sources in Fig. 2, 3.

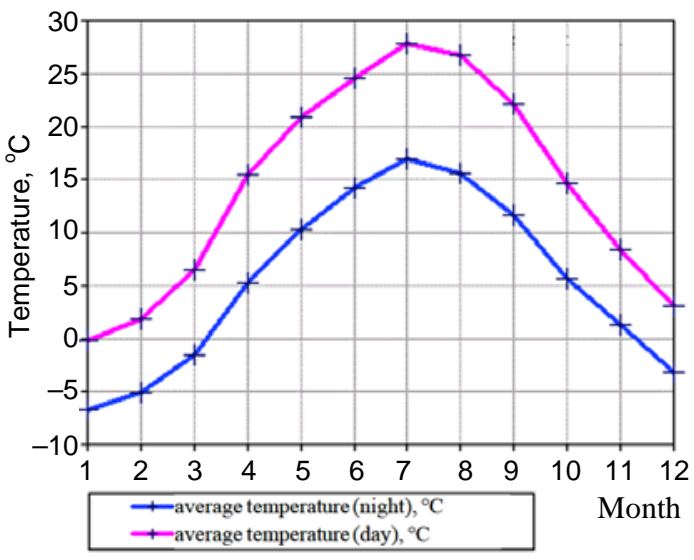

Fig. 2. Averaged climate data for Stavropol

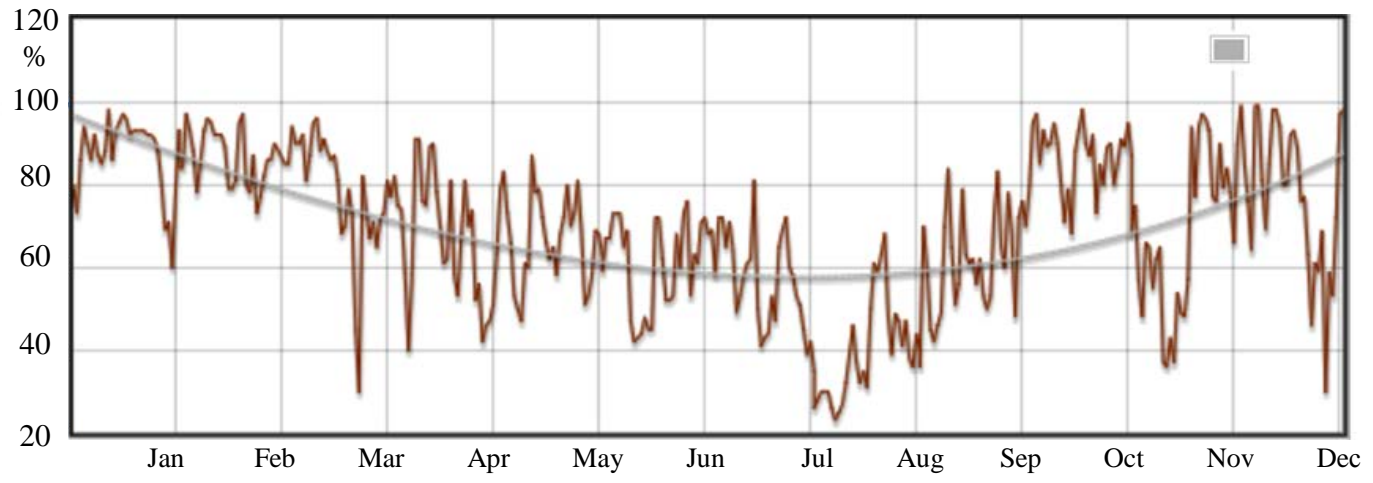

Fig. 3. Chart of the average annual relative humidity outdoor air for Stavropol 
In general terms, the effect of changing the parameters of exergy reference point can be shown in the $h$-S-diagram (Fig. 4).

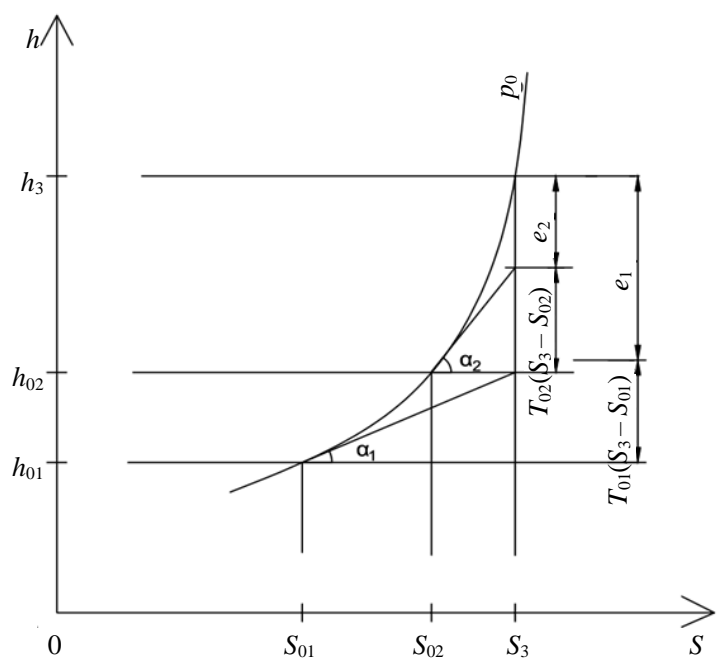

Fig. 4. Change of the outdoor air exergy value through changes in climatic parameters

In general terms, according to the definition of the exergy of flow:

$$
\frac{e_{1}}{e_{2}}=\frac{c_{p}\left(T_{3}-T_{01}\right)-T_{01}\left(S_{3}-S_{01}\right)}{c_{p}\left(T_{3}-T_{02}\right)-T_{02}\left(S_{3}-S_{02}\right)} \neq 1,
$$

where $e_{1}$ - exergy of the lower limit of the amplitude of fluctuation of temperature or humidity, $\mathrm{kJ} / \mathrm{kg} ; e_{2}$ - exergy of the upper limit of the amplitude of fluctuation of temperature or humidity, $\mathrm{kJ} / \mathrm{kg} ; c_{p}$ - heat capacity of moist air at constant pressure, $\mathrm{kJ} /(\mathrm{kg} \cdot \mathrm{K}) ; T_{3}$ - temperature of the flow of moist air, $\mathrm{K} ; \mathrm{T}_{01}$ - ambient temperature of the lower limit of the amplitude of climate fluctuation $\left(\operatorname{tg} \alpha_{1}\right), K ; T_{02}$ - ambient temperature of the upper limit of the amplitude of climate fluctuation $\left(\operatorname{tg} \alpha_{1}\right), \mathrm{K} ; S_{3}$ - entropy of the flow of moist air, $\mathrm{kJ} / \mathrm{kg} ; S_{01}$ - entropy of the environment of the lower limit of the amplitude of fluctuation of climate parameters, $\mathrm{kJ} / \mathrm{kg}$; $S_{02}$ - entropy of the environment of the upper limit of the amplitude of climate fluctuation, $\mathrm{kJ} / \mathrm{kg}$.

Thus, it follows from expression (11) that the same flow of moist air has a different exergy value due to a change in parameters of the exergy reference point. We will determine within what limits this change in exergy can be wrong. Exergy of a moist air flow $\left(e_{\text {air }}\right)$ is calculated by the formula from the publication [16]:

$$
\begin{gathered}
e_{\text {air }}=T_{0}\left\{\left(\frac{T_{x}}{T_{0}}-1-\ln \frac{T_{x}}{T_{0}}\right)\left(c_{p}+d_{x} c_{\text {pair }}\right)+\right. \\
\left.+R_{\text {air }}\left(\left(0,622+d_{x}\right) \ln \frac{\left(0,622+d_{0}\right) p_{x}}{\left(0,622+d_{x}\right) p_{0}}+d_{x} \ln \frac{d_{x}}{d_{0}}\right)\right\},
\end{gathered}
$$

where $e_{\text {air }}$ - exergy of a moist air flow; $T_{x}$ - temperature of the flow of moist air, $\mathrm{K} ; T_{0}-$ ambient temperature, $\mathrm{K} ; d_{x}-$ moisture content of the flow of moist air, $\mathrm{kg} / \mathrm{kg} ; c_{\text {pair }}$ - isobaric heat capacity, $\mathrm{J} /\left(\mathrm{kg} \cdot{ }^{\circ} \mathrm{C}\right) ; R_{\text {air }}$ - universal gas constant for dry air, $\mathrm{J} /(\mathrm{K} \cdot \mathrm{mol}) ; d_{0}-$ moisture content of the environment, $\mathrm{kg} / \mathrm{kg} ; p_{x}$ - pressure of moist air in the flow, Pa; $p_{0}$ - atmospheric pressure of the environment, $\mathrm{Pa}$.

Using formula (2), we will calculate the exergy of the flow relative to the extreme values of fluctuation of characteristics of moist air and compare with the exergy relative to the constant indoor parameters $\left(e_{0}\right)$. To do this, let us set a flow of moist air with the parameters: $t=30^{\circ} \mathrm{C}, \varphi=60 \%$. When using the exergy analysis in air conditioning systems, it is necessary to choose not only the temperature but also a representative value of humidity in the room which is constant and ensures comfortable conditions for people. The results of calculations with the selected parameters are summarized in Tab. 1.

Table 1

Value of exergy of a flow of moist air relative to the extreme points of fluctuation in climate and air parameters in the room

\begin{tabular}{|c|c|c|c|c|c|}
\hline Season & \multicolumn{2}{|c|}{ Summer } & \multicolumn{2}{c|}{ Winter } & $\begin{array}{c}\text { Air } \\
\text { parameters } \\
\text { in the room }\end{array}$ \\
\hline Time of day & Night & Day & Night & Day & \\
\hline$t,{ }^{\circ} \mathrm{C}$ & 17 & 27 & -7 & 0 & 20 \\
\hline$d, \mathrm{~g} / \mathrm{kg}$, dry air & 9.668 & 8.889 & 1.773 & 3.000 & 7.260 \\
\hline$\varphi, \%$ & 80 & 40 & 80 & 80 & 50 \\
\hline$e, \mathrm{~kJ} / \mathrm{kg}$ & 0.520 & 0.332 & 5.000 & 3.320 & 0.697 \\
\hline$e / e_{0}$ & 0.75 & 0.48 & 7.17 & 4.76 & 1.00 \\
\hline
\end{tabular}

Tab. 1 shows that ratio $e / e_{0}$ ranges from 0.48 to 7.17. The above data indicate that it is necessary to carefully justify the choice of the reference point in open systems. According to the authors, the internal air environment of a building with air parameters maintained at an almost constant heat and humidity level (Fig. 5) can be used as the possible definition of the zero level of exergy. 


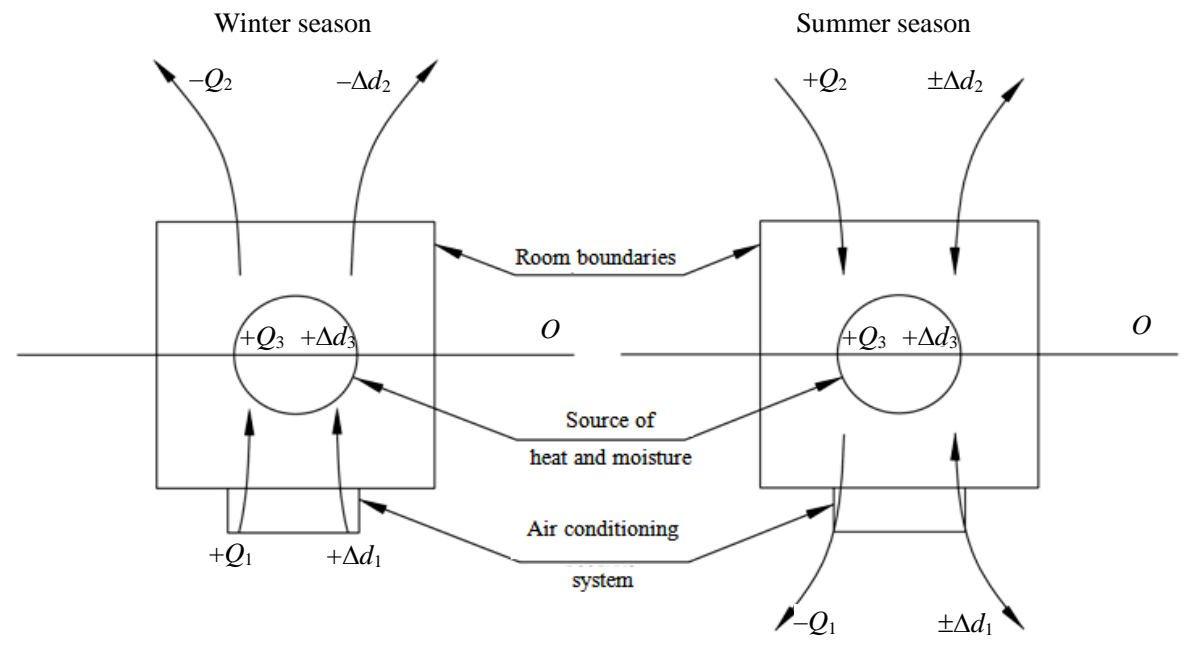

Fig. 5. Representation of heat and moisture balances in the room during summer and winter seasons

Fig. 5 uses the following notation: $Q_{1}, \Delta d_{1}-$ heat and moisture transport realized by the air conditioning system; $Q_{2}, \Delta d_{2}$ - heat and mass exchange of the room with the environment (heat input, heat loss and moisture penetration during summer or winter season); $Q_{3}, \Delta d_{3}$ - excess heat and moisture inside the room during winter or summer.

This constancy of internal parameters is achieved by the operation of heating, ventilation and air conditioning systems. The operation of one of the simplest air conditioning systems [17-19] (Fig. 6) for the summer and winter seasons on the basis of the entered exergy reference point can be represented by the diagram shown in Fig. 7. Fig. 6, 7 uses the following notation: $O\left(O^{\prime}\right)-$ parameters of outdoor air during winter (summer) season; $M\left(M^{\prime}\right)$ - air parameters at the outlet from the mixing chamber during winter (summer) season; $C$ - air parameters at the outlet from the preheating calorifer; $W$ - air parameters at the outlet from the air washer; $I$ - air parameters at the outlet from the reheat calorifer (inlet air); $R$ - air parameters in the room; $R^{\prime}$ - air parameters in the recirculation air duct (it is assumed that the process $R-R^{\prime}$ goes along $d=$ const, that is, the temperature gradient in the room is not taken into account; since the air intake for recirculation comes from the working area of the room, when accounting for it the process $R-R^{\prime}$ goes along $\varepsilon=$ const); $E_{\text {inlet }}$ - exergy of the inlet air flow; $\Delta E_{1}\left(\Delta E_{1}^{\prime}\right)-$ variation of exergy of the moist air flow (the pro- cess of its conditioning) during winter (summer) season; $\Delta E_{2}\left(\Delta E_{2}^{\prime}\right)$ - variation of exergy of the moist air flow in the reheat air heater during winter (summer) season; $\Delta E_{3}\left(\Delta E_{3}^{\prime}\right)$ - variation of exergy of the moist air flow in the humidifier during winter (summer) season; $\Delta E_{4}$ - variation of exergy of the flow of moist air in the preheating air heater ( $\Delta E_{4}^{\prime}-$ turned off during summer season, but creates aerodynamic drag); $\Delta E_{5}\left(\Delta E_{5}^{\prime}\right)-$ variation of exergy of the moist air flow in the mixing chamber during winter (summer) season.

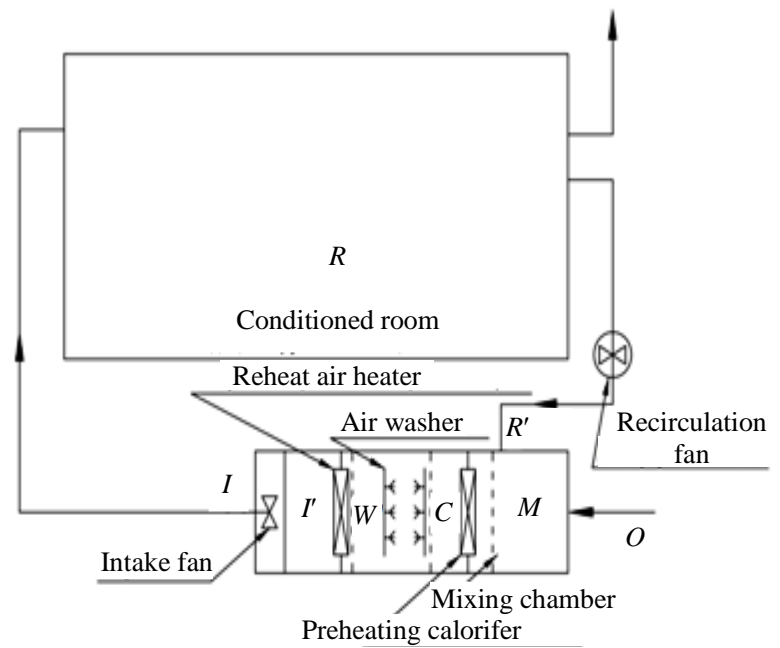

Fig. 6. Schematic diagram of air conditioning during winter season with the recirculation (before heater)

Representation of the process of heat and moisture treatment of the inlet air in the $h$-d-diagram is shown in Fig. 8, 9 [20]. 


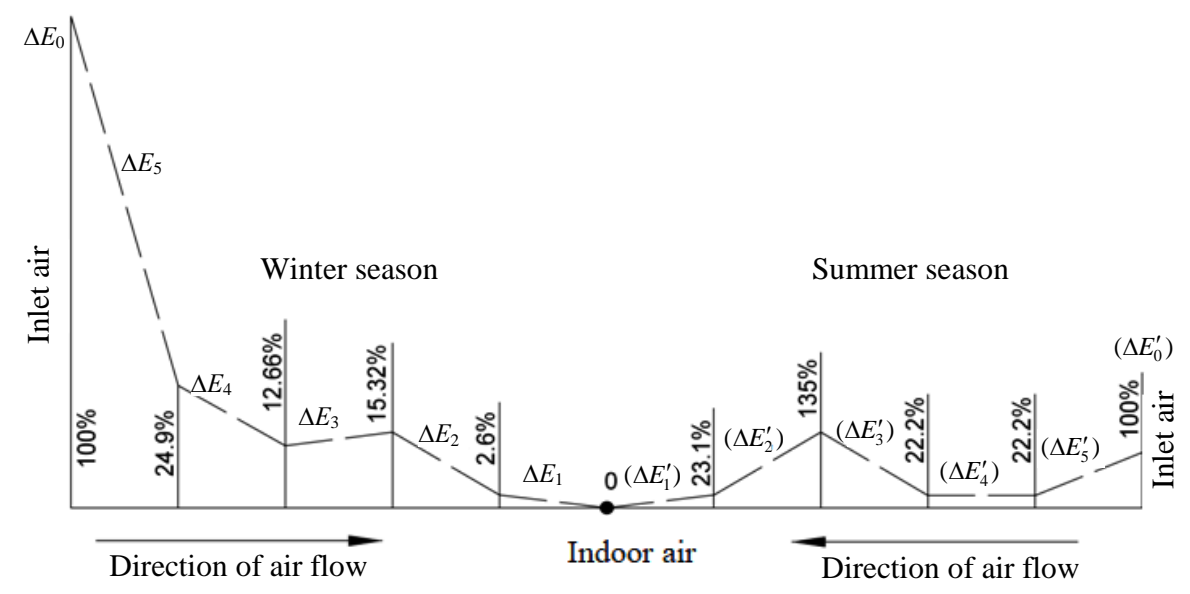

Fig. 7. Diagram of moist air flow exergy variation

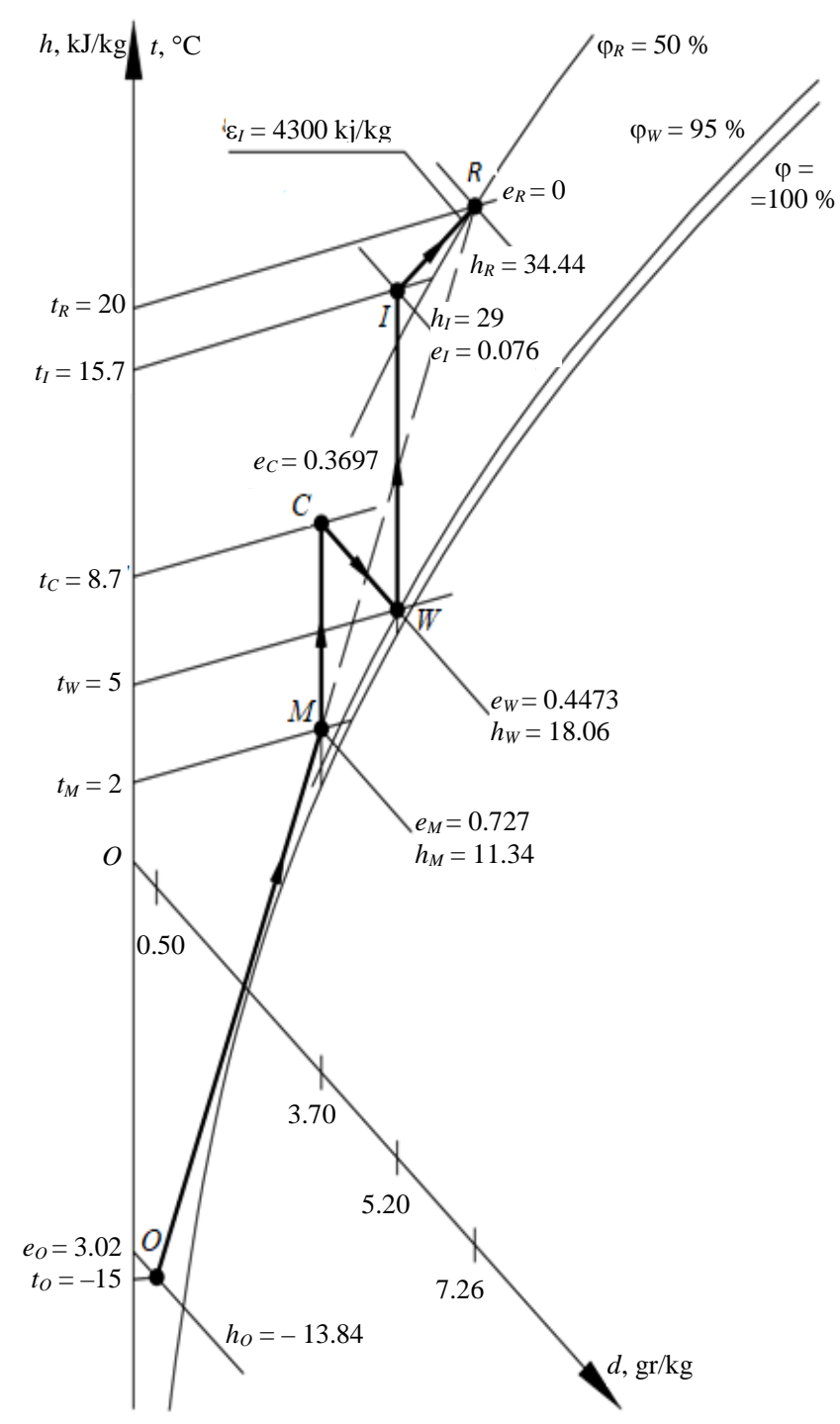

Fig. 8. Representing the process of air conditioning during winter season with recirculation in the $h$-d-diagram

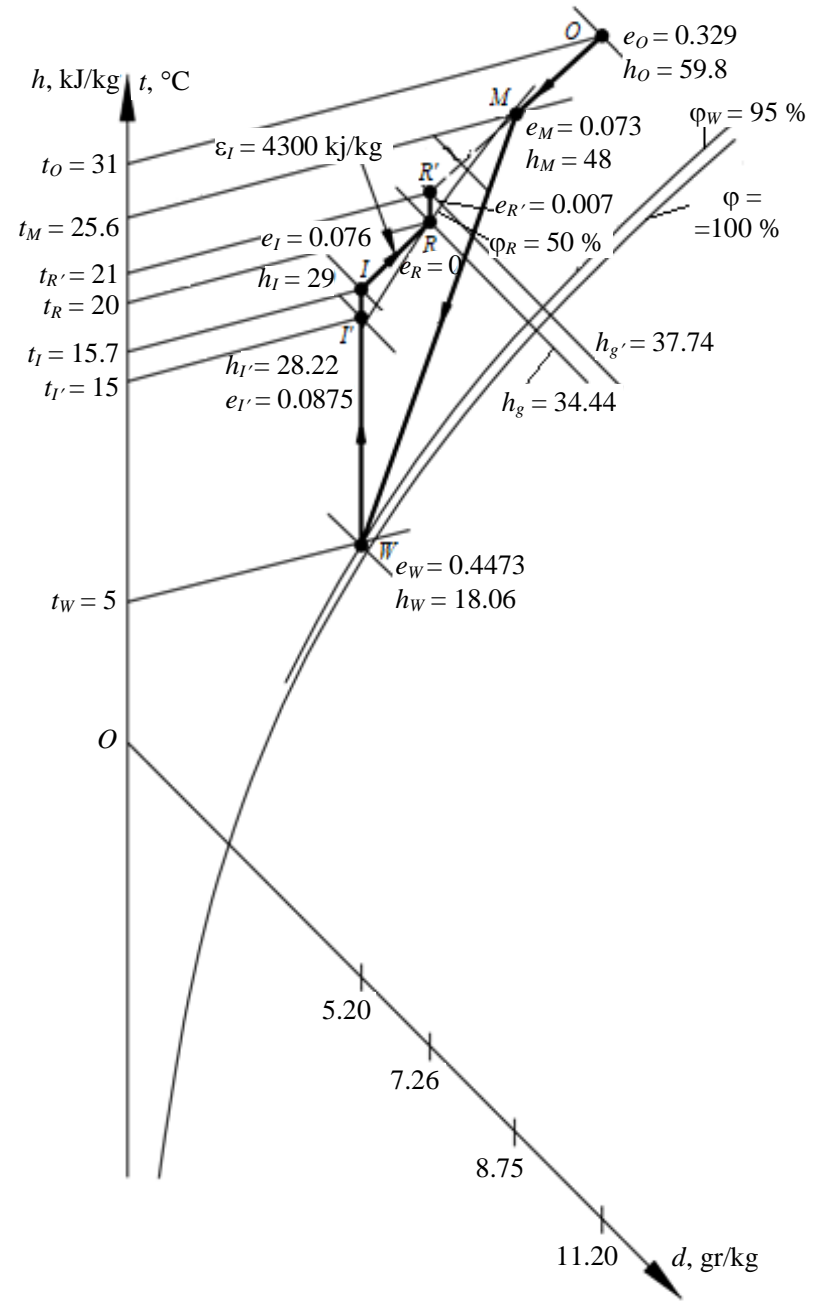

Fig. 9. Representing the process of air conditioning during summer season with the recirculation and second heating in the $h$-d-diagram 


\section{CONCLUSIONS}

1. The proposed reference level of the exergy has a number of advantages in comparison with the variable reference point according to the outdoor air parameters. The most important advantage is the greater stability of the values and marks of the air exergy flow. This fact makes it possible to simplify the calculations of the efficiency of the air conditioning installation as well as its units. Also, the reference level of exergy proposed in this paper is close in its parameters to the commonly applied parameters of the so-called "technical" atmosphere and allows building a new diagram of the change in the exergy of the flow in the air conditioning system.

2. The analysis shows that the increase in the exergy efficiency of the air conditioning system and its units depends primarily on the reduction in expenditures of electrical energy and optimization of processes in the heat-and-mass exchange apparatus of air handling. First of all, it concerns such units as the mixing chamber and the air washer.

\section{REFERENCES}

1. Brodyansky V. M. (1973) Exergy Method of Thermodynamical Analyses. Moscow, Energiya Publ. 296 (in Russian).

2. Shukuya M. (2013) Exergy: Theory and Applications in the Built Environment. Springer. 374. https://doi.org/10. 1007/978-1-4471-4573-8.

3. Dincer I., Rosen M. A. (2013) Exergy. Energy, Environment and Sustainable Development. $2^{\text {nd }}$ ed. Elsevier. 552. https://doi.org/10.1016/C2010-0-68369-6.

4. Dincer I., Rosen M. A. (2011) Thermal Energy Storage: Systems and Applications. John Wiley \& Sons, Ltd. 621. https://doi.org/10.1002/9780470970751.

5. Baldi M. G., Leoncini L. (2014) Thermal Exergy Analysis of a Building. Energy Procedia, 62, 723-732. https://doi. org/10.1016/j.egypro.2014.12.436.

6. Gendelis S., Jakovičs A., Bandeniece L. (2015) Experimental Research of Thermal Comfort Conditions in Small Test Buildings with Different Types of Heating. Energy Procedia, 78, 2929-2934. https://doi.org/10.1016/j.egypro. 2015.11.669.

7. Ahmad M. W., Moursheda M., Mundowb D., Sisinni M., Rezgui Y. (2016) Building Energy Metering and Environmental Monitoring - a State-of-the-Art Review and
Directions for Future Research. Energy and Buildings, 120, 85-102. https://doi.org/10.1016/j.enbuild. 2016.03.059.

8. Nasutiona H., Sumerub K., Aziza A. A., Senawib M. Y. (2014) Experimental Study of Air Conditioning Control System for Building Energy Saving. Energy Procedia, 61, 63-66. https://doi.org/10.1016/j.egypro.2014.11.907.

9. Luoa Q., Yanga L., Liu N. X., Xia J. (2015) Comparative Study on Thermal Environment and Energy Consumption of Urban Residential Houses in Beijing. Procedia Engineering, 121, 2141-2148. https://doi.org/10.1016/j.proeng. 2015.09.085.

10. Baldi M. G., Leoncini L. (2015) Effect of Reference State Characteristics on the Thermal Exergy Analysis of a Building. Energy Procedia, 83, 177-186. https://doi.org/10. 1016/j.egypro.2015.12.208.

11. Zhou X., Li N., Zou J. (2015) Research on Energy-Saving of New Type Low-Temperature Air Flow Dehumidification System Based on Exergy Analysis Method. Procedia Engineering, 121, 268-276. https://doi.org/10.1016/j. proeng.2015.08.1068.

12. Vilarinho A. N., Campos J. B. L. M., Pinho C. (2016) Energy and Exergy Analysis of an Aromatics Plant. Case Studies in Thermal Engineering, 8, 115-127. https://doi. org/10.1016/j.csite.2016.06.003.

13. Meteo Info. (2017) Available at: http://www.meteoinfo.ru (in Russian).

14. Weather Atlas. (2017) Available at: http://www.atlas-yaku tia.ru/weather/hum/climate_russia-III_hum.html (in Russian).

15. Xu W. H., Li Q. X., Yang S., Xu Y. (2014) Overview of Global Monthly Surface Temperature Data in the Past Century and Preliminary Integration. Advances in Climate Change Research, 5, 111-117. https://doi.org/10.1016/j. accre.2014.11.003.

16. Prokhorov V. I., Shilkloper S. M. (1981) Method of Calculation of Exergy Flow of Moist Air. Kholodilnaya Tekhni$k a=$ Refrigeration Technology, (9), 37-40 (in Russian).

17. Minkin M. S., Kuimov D. N., Lukyanov A. D. (2016) Development of the Energy-Saving Air Regeneration System in Production Rooms. Procedia Engineering, 150, 1353-1358. https://doi.org/10.1016/j.proeng.2016.07.327.

18. Sukhodub I. O., Deshko V. I. (2014) Exergy Analysis of Ventilation Systems with Energy Recovery. Magazine of Civil Engineering, 2 (46), 36-46.

19. Titova E. M., Averyanova O. V. (2011) Efficiency Evaluating of Air Conditioning System with Air Dehumidification Section. Magazine of Civil Engineering, 1 (19), 46-52.

20. Nesterenko A. V. (1971) Fundamentals in Thermodynamic Calculations of Ventilation and Air Conditioning. Moscow, Vishaya Shkola Publ. 460 (in Russian).

Received: 24.12.2019

Accepted: 04.10.2021

Published online: 28.01.2022 